8-17-2012

\title{
Multinational Enterprise Competition: Grounding The Eclectic Paradigm Of Foreign Production In Resource-Advantage Theory
}

Dennis E. Arnett

Texas Tech University, dennis.arnett@ttu.edu

Sreedhar Madhavaram

Cleveland State University, s.madhavaram@csuohio.edu

Follow this and additional works at: https://engagedscholarship.csuohio.edu/bus_facpub

Part of the International Business Commons

How does access to this work benefit you? Let us know!

\section{Publisher's Statement}

NOTICE: this is the author's version of a work that was accepted for publication in the Journal of Business \& Industrial Marketing. Changes resulting from the publishing process, such as peer review, editing, corrections, structural formatting, and other quality control mechanisms may not be reflected in this document. Changes may have been made to this work since it was submitted for publication. A definitive version was subsequently published in Journal of Business \& Industrial Marketing, 27, 7, 08-17-2012, 10.1108/08858621211257347.

\section{Original Published Citation}

Arnett, D.B. \& Madhavaram, S. (2012). Multinational enterprise competition: Grounding the eclectic paradigm of foreign production in resource-advantage theory. Journal of Business \& Industrial Marketing, 27(7), 572-581. doi: 10.1108/08858621211257347

This Article is brought to you for free and open access by the Monte Ahuja College of Business at EngagedScholarship@CSU. It has been accepted for inclusion in Business Faculty Publications by an authorized administrator of EngagedScholarship@CSU. For more information, please contact library.es@csuohio.edu. 


\title{
Multinational enterprise competition: grounding the eclectic paradigm of foreign production in resource-advantage theory
}

\author{
Dennis B. Arnett \\ Area of Marketing, Texas Tech University, Lubbock, Texas, USA and Area of Marketing, Buskerud University College, Hønefoss, \\ Norway, and \\ Sreedhar Madhavaram \\ Department of Marketing, Cleveland State University, Cleveland, Ohio, USA
}

\begin{abstract}
Purpose - This paper seeks to explicate a dynamic theory of competition, i.e. the resource-advantage theory of competition, with the aim of developing a theoretical foundation for the eclectic paradigm of foreign production.

Design/methodology/approach - The paper is conceptual in approach.

Findings - The paper develops a set of five criteria that should be met by any theory that attempts to ground the eclectic paradigm. In addition, it demonstrates that the resource-advantage theory of competition meets all of these criteria.

Research limitations/implications - By providing a theoretical foundation for the eclectic paradigm of foreign production, the paper provides researchers with a broader perspective from which to investigate multinational enterprise competition.

Originality/value - The usefulness of frameworks, such as the eclectic paradigm of foreign production, is limited when they are not grounded in positive theories. By grounding the eclectic paradigm of foreign production, this paper enhances the paradigm's usefulness.
\end{abstract}

Keywords Multinational enterprise competition, Eclectic paradigm, Resource-advantage theory, Production management, Resource management

Paper type Conceptual paper

Understanding how multinational enterprises compete is the goal of much of international business research. However, due to the complexities involved in firms competing in multiple countries, no general theory has been able to explain fully the mechanisms involved. Therefore, insights into multinational enterprise (MNE) competition have been guided by various research streams, including transaction cost analysis (e.g. Graham, 1998, Horaguchi and Toyne, 1990), imperfect competition (e.g. Grosse, 1985), institutional theory (e.g. Dacin et al., 2002; Kostova et al., 2008), and internationalization theory (e.g. Buckley, 1988; Rugman, 1982). However, one research stream, the eclectic paradigm (or framework) of foreign production (e.g. Dunning, 1980, 1988, 1998, 2001; Dunning and Lundan, 2008), hereafter the eclectic paradigm, has inspired a considerable amount of research into the activities of MNEs (Guisinger, 2001). Indeed, as Cantwell and Narula (2001) emphasize, "the eclectic paradigm has been the leading explanation for the growth of multinational activity over the past two decades".

The eclectic paradigm is a unifying framework for determining the extent and pattern of foreign direct investment by MNEs (Dunning, 2001). It stresses that foreign direct investments by MNEs are determined by three sets of forces referred to by the acronym OLI (ownership advantages, location advantages, and internalization advantages). Ownership advantages (or firm-specific advantages) are comprised of the capabilities and assets that provide competitive advantages to a firm. Location advantages delineate those advantages gained from operating in a particular country (e.g. access to raw materials, low wage rates, etc.). Internalization advantages are the advantages that a firm gains by using its ownership advantages itself rather than selling them (or making them available) to other firms. The existence and configuration of the OLI factors influence firms' decisions to engage in foreign activities (Moore and Lewis, 1999).

Early works outlining the eclectic paradigm suggest that it could be developed into a "theory" of international production. This is evident in early titles, such as "Toward an eclectic theory of international production" (Dunning, 1980) (see also Dunning and McQueen, 1981; Dunning and Norman, 1983). However, by the mid-1980s, it was being characterized as simply a paradigm rather than a theory. Dunning (2001, p. 176) emphasizes the belief that "No single theory can be expected to satisfactorily encompass all kinds of foreign-owned value-added activity". Indeed, as the term "eclectic" suggests, the framework is not a single theory; rather it is a compilation of complementary and alternative theories that together explain the level and pattern of valueadded activities of MNEs (Tolentino, 2001). However, as Hunt and Madhavaram (2006) argue, conceptual frameworks are more useful when they are grounded in theory. The success of the eclectic paradigm suggests that, perhaps, there could be discovered some systematically related set of statements (including some law-like generalizations) that is 
empirically testable, which can be used to ground the eclectic paradigm[1]. That is, there may exist a general theory broad enough to enable both the explanation and prediction of the phenomena that are covered by the eclectic paradigm.

The purpose of this article is to explicate a dynamic, theory of competition with the aim of developing a theoretical foundation for the eclectic paradigm. Recent developments have made such a foundation possible. First, Dunning (2003) and Dunning and Lundan (2008) suggest that the resourcebased theory of the firm informs the eclectic paradigm. Second, the resource advantage theory of competition (R-A theory hereafter) has been put forth as a general theory of competition (Hunt, 2000b). As such, R-A theory should be capable of providing a theoretical foundation for all forms of competition, including MNE competition.

The article is organized as follows. First, we provide a discussion of the eclectic paradigm and develop a set of five criteria based on Dunning (1980, 1988, 1998, 2001) that should be met by any theory that attempts to ground theoretically the eclectic paradigm. These criteria are argued to be:

- ownership advantages, location advantages, and internalization advantages should be allowed to affect MNE performance;

- firms should be able to develop sustainable advantages in resources over rivals (i.e. homogeneous, perfectly mobile resources should not be assumed);

- resources should be spatially transferable;

- country specific factors (i.e. context variables) should impact MNE competition; and

- the theory should be capable of capturing the dynamic nature of MNE competition (see Table I).

Second, we examine extant theories of competition in mainstream economics to show why none provide a theoretical foundation for the eclectic paradigm. Third, we provide a brief overview of R-A theory. Fourth, we discuss RA theory's ability to provide a theoretical foundation for the eclectic paradigm. Specifically, we will explore whether R-A theory accommodates the five requisites presented in Table I. Fifth, we conclude with suggestions for further research.

\section{The eclectic paradigm}

The eclectic paradigm was developed as a holistic framework that can identify and evaluate the significance of the factors influencing both the initial act of foreign production by enterprises and the growth of foreign production (Dunning, 1988). As Dunning (1980) argues, the extent to which MNEs

Table I Five requisites for grounding the eclectic paradigm

1 Ownership advantages, location advantages, and internalization advantages should be allowed to affect MNE performance

2 Firms should be able to develop sustainable advantages in resources over rivals (i.e. homogeneous, perfectly mobile resources should not be assumed)

3 Resources should be spatially transferable

4 Country specific factors (i.e. context variables) should impact MNE competition

5 The theory should be capable of capturing the dynamic nature of MNE competition engage in foreign direct investment rests on three determinants:

1 the extent to which firms possess (or can gain access to) resources (or assets) that rivals lack;

2 the extent to which it is in the best interest of firms to internalize the resources rather than sell or lease them to other firms; and

3 the extent to which the resources complement the indigenous resources of the foreign countries in which they do business.

For the eclectic paradigm, resources are manifested in ownership advantages, locations advantages, and internalization advantages. It maintains that MNEs often have certain resource advantages over rivals. As Dunning (1988, p. 2) states, "in order for firms of one nationality to compete with those of another by producing in the latter's own countries, they must possess certain advantages specific to the nature and/or nationality of their ownership". In other words, foreign direct investments strategies make sense only if firms are capable of having firm-specific resource advantages over rivals in foreign countries. As Dunning (2001, p. 175) asserts, "a firm that makes a foreign acquisition to obtain new and up-to-date technology or managerial capabilities presumably does so because it believes it can use such assets along with existing core competences in a way which will protect or augment its competitive position".

Ownership advantages can be viewed as resulting from firm-specific advantages or resources (Moore and Lewis, 1999). As Dunning (1988) suggests, ownership advantages can arise from ownership of, or access to (vis-à-vis external markets), specific resources. Therefore, ownership advantages depend not only upon resources generated internally but also on the competence to seek out and harness resources generated by other organizations (Dunning, 2001). The eclectic paradigm suggests that ownership advantages affect the strategies that firms use. For example, firms that have ownership advantages over rivals in foreign markets often chose to use a strategy of foreign direct investment (Dunning, 1998). However, the use of ownership advantages is often contingent on other factors such as location advantages.

Location advantages result from a firm using marketplace characteristics to its advantage. "Enterprises will engage in foreign production whenever they perceive it is in their best interests to combine spatially transferable intermediate products produced in the home country, with at least some immobile factor endowments or other intermediate products in other countries" (Dunning, 1988, p. 4). In other words, firms use a combination of ownership advantages and location advantages to compete with rivals. This is consistent with the strategy followed by many countries of developing "businessfriendly" resources (e.g. modern infrastructures, tax incentives, etc.) in an attempt to attract investments by foreign businesses.

Ownership advantages must complement location advantages. Indeed, as Dunning (1998, p. 59) maintains, "it may be preferable to think of the MNE not as a second best substitute for the market, but as a partner with the market to promote first-best allocative efficiency throughout and across value chains". Firms will choose foreign direct investment strategies when their ownership advantages combined with location advantages are perceived to be better than those of rival firms. The implicit assumption here is that firms are 
capable of using resources across national boundaries (Dunning, 1988). Indeed, this premise was present early in the development of the eclectic paradigm. For example, Dunning (1958) argues that firms that that are more effective at harnessing and organizing resources should be able, at least to some extent, to transfer these advantages across national boundaries.

Internalization advantages refer to the situation where firms gain advantages over rivals by transferring ownership-specific advantages "across national boundaries within their own organizations rather than sell them, or their right of use to foreign-based enterprises" (Dunning, 1988, p. 3). For example, a firm may decide to build a production facility in a foreign country rather than license the process to other firms in that country. The eclectic paradigm suggests that firms will internalize ownership advantages when such actions can increase the firm's financial performance. Although internalization is often viewed as an efficiency choice (i.e. from a transaction cost perspective), the decision to internalize often revolves around the issue of control (Moore and Lewis, 1999). Once an ownership advantage (e.g. market knowledge) is made available to other firms (e.g. via licensing agreements or partnerships) it becomes difficult to maintain control over it. As Moore and Lewis (1999) note, once the ownership advantages change hands, it is difficult for MNEs to control what competitors dos with the process and to ensure that they do not sell it on to other competitors at a low price.

The dynamism of the eclectic paradigm is the result of "the continuous and iterative interaction between OLI configuration over successive time periods and the strategy of firms in response to these configurations that, in turn, influence the OLI configuration in a subsequent moment in time" (Dunning, 2001, p. 178). Firms react to the successes and failures of rivals. When the successes of rivals threaten to decrease the advantages that firms enjoy, they often engage in strategies designed to safeguard (or increase) current advantages. These strategies, in turn, result in changes in the OLI configurations of the firms in future time periods. This process continues as long as rivals exist.

Given the characteristics of the eclectic paradigm, a general theory of competition that could potentially ground the eclectic paradigm would, at least, satisfy five requisites (see Table I). First, ownership advantages, location advantages, and internalization advantages should be allowed to affect MNE performance. As Dunning (1980) suggests, firms choose to engage in foreign direct investment when they believe that their combinations of ownerships advantages, location advantages, and internalization advantages will allow them to increase their profits. Second, firms should be able to develop sustainable advantages in resources over rivals (i.e. homogeneous, perfectly mobile resources should not be assumed). Firms must be capable of possessing resource advantages over rivals sufficient enough to outweigh the costs of servicing unfamiliar or distant markets (Dunning, 1980).

Third, resources should be spatially transferable. That is, firms should be capable of using resources in multiple markets. As Dunning (1988) maintains, to engage in a strategy of foreign direct investment, firms must be capable of transferring at least some of their ownership advantages across national boundaries within their own firms. Otherwise, foreign direct investment would not make sense. Fourth, country specific factors (i.e. context variables) should impact
MNE competition. The decision of where to locate a production facility is influenced considerably by factors such as locally available resources, trade barriers, and/or the formation of regional trading blocs (Dunning, 1980). Fifth, the theory should be capable of capturing the dynamic nature of MNE competition. That is, the theory should be capable of explaining the relationships among ownership advantages, location advantages, and internalization advantages over time.

\section{The eclectic paradigm and mainstream economic theories of competition}

The neoclassical theory of competition has become the most dominant theory of competition taught in colleges (Hunt and Morgan, 1995). For mainstream economics, "competition" means perfect competition, with the full array of required conditions. For perfect competition, the firm is not considered to be an efficient mechanism for transferring resources across national boundaries; instead, the market is proffered as the most efficient mechanism for such transfers (Dunning, 1988). As a result, firms should not choose to internalize advantages because the market will always be a more efficient allocator of resources. Therefore, the concept that firms would choose to internalize advantages to gain efficiencies or advantages over rival firms is foreign to neoclassical theory. As a result, the neoclassical theory of competition is unable to provide a theoretical justification for internalization advantages and, therefore, it cannot provide a theoretical foundation for the eclectic paradigm.

Similarly, "new" institutional economics (NIE) (Williamson, 1975, 1985, 1996) cannot provide a theoretical foundation for the eclectic paradigm. NIE represents an important step in the development of a theory of the firm (Foss, 1996). Prior to NIE, mainstream economic theory tended to treat the firm as a "black box", which was not worthy of study. NIE provides important insights into the governance structures of MNEs. However, it does not provide a mechanism to explain how OLI advantages affect firm performance. In general, NIE neglects the fact that firms engage in activities designed to increase effectiveness (Hunt, 2000b). Instead, NIE focuses on firm efficiency. As Coase (1988) concludes, NIE has tended to neglect the main activity of a firm, i.e. running a business. As a result, it cannot provide a theoretical basis for the eclectic paradigm.

An examination of mainstream economics reveals that no theory of the fundamental nature of competition can provide a theoretical foundation for the specific combinations of general theories that comprise the eclectic paradigm. What is required is a theory that describes the process of competition. As Burt (1992, pp. 5-6) emphasizes:

Competition is a process not a result. With important exceptions, most theories of competition concern what is left when competition is over. They are an aside in efforts to answer the question of how to maximize producer profit [...]. The alternative is to start with the process of competition and work toward its results. This is a less elegant route for theory, but one that veers closer to the reality of competition as we experience it.

\section{An overview of R-A theory}

R-A theory is a general theory of competition that describes the process of competition, which is explicated using a descriptive approach (Hunt and Arnett, 2001)[2]. Being a general theory of competition, R-A theory shares affinities 
with other theories. In general, it combines of heterogeneous demand theory (Alderson, 1965) with the resource-based theory of the firm[3]. The resource-based theory of the firm can be traced to Penrose (1959) and Wernerfelt (1984). This view parallels, if not undergirds, what Foss (1993) calls the "competence perspective" in evolutionary economics and the "capabilities" approaches of Teece and Pisano (1994) and Langlois and Robertson (1995) (Hunt, 2000b). However, RA theory is more than a compellation of these theories. Rather, it is the kind of "synthesis theory" called for by Smelser and Swedberg (1994).

R-A theory defines competition as "the constant struggle among firms for comparative advantages in resources that will yield marketplace positions of competitive advantage for some market segment(s) and, thereby, superior financial performance" (Hunt, 2000b, p. 135). The key aspect of competition, as is implied by the theory's name, is a firm's ability to develop and maintain advantages in resources over its rivals. However, to understand R-A theory one must first have an understanding of seven fundamental components (four basic concepts and three processes) of the theory. As suggested by the definition of competition above, competition involves four basic concepts:

1 resources;

2 competitive advantage;

3 market segments; and

4 superior financial performance.

In addition, there are three processes that are alluded to in the definition of competition:

1 the struggle for comparative advantages in resources;

2 the development of marketplace positions of competitive advantage; and

3 the realization of superior financial performance.

Our discussion of the theory focuses on these major concepts.

Resources and the struggle for comparative advantages For R-A theory, resources are tangible and intangible entities available to the firm that enable it to produce efficiently and/ or effectively a market offering that has value for some market segment(s) (Hunt and Morgan, 1995). At their basic level, resources can be classified as financial (e.g. cash reserves, access to financial markets), physical (e.g. office equipment, production equipment), legal (e.g. contracts with suppliers, trademarks, copyrights), human (e.g. skills and knowledge of employees), organizational (e.g. culture, structure, procedures), informational (e.g. market research, competitive intelligence), and relational (e.g. relationships with partners, suppliers, and customers). Firms need not own a resource to take advantage of it. All that is necessary is that firms have access to resources. Indeed, many strategic partnerships are formed so that participating firms can gain access to each other's resources (Lambe et al., 2002; Wittmann et al., 2009).

Resources can also be combined into complex or "higher order" resources. For example, a firm's ability to develop innovative products can be considered a higher order resource because it requires the firm to use a combination of basic resources. That is, to develop innovative products a firm must use the knowledge and skills of its employees (a human resource), its computer equipment (a physical resource), market research (an informational resource), and other basic resources. If the basic resources used fit coherently together in a synergistic manner and lead to increases in the effectiveness and/or efficiency of the firm, they become competencies (Hunt, 2000b). For example, Southwest Airlines in known for being on time, which could be considered one of its competencies. This competence is a result of the procedures that the firm developed to shorten the amount of time its aircraft spend on the ground (e.g. cleaning, restocking, etc.), the skills and knowledge of the airline's employees, and Southwest Airlines' ability to motivate its employees. The increases in efficiency have allowed Southwest Airlines to service its routes with fewer planes than other airlines (Feldman, 2001).

Firms can gain an advantage in resources over their rivals because resources are significantly heterogeneous across firms and imperfectly mobile (Hunt and Morgan, 1995; Hunt, 2000 b). Although firms can possess similar resource sets, the compilation of a firm's set of resources is unique. That is, the complexities of resource sets ensure that they cannot be duplicated exactly. For example, though some resources that firms use (e.g. computers, desks, and buildings) can be obtained easily by rival firms, others are more difficult to procure due to their complex natures (e.g. relationships with suppliers and customers). As Hunt (2000b) suggests, it is the complexity of resource sets that makes it difficult for firms to easily trade, buy, and/or sell them (i.e. they are imperfectly mobile). However, because comparative advantages in resources are difficult to acquire, they can persist over time.

\section{Market segments and marketplace positions of competitive advantage}

Firms can have a comparative advantage in resources in particular market segments - intra-industry groups of consumers whose tastes and preferences with regard to an industry's output are relatively homogeneous (Hunt, 2000b). A comparative advantage in resources occurs when a firm's available resources enable it to produce a market offering that is perceived by consumers as being more valuable than rivals' market offerings and/or enable it to produce a market offering at lower costs than rivals. A firm's marketplace position is defined by its relative resource costs and the relative perceived value of its market offerings.

A firm will have a marketplace advantage in a given segment, if it can produce:

- a market offering perceived as having superior value compared to rivals' marketing offerings at a lower cost than rivals; or

- a market offering perceived as having superior value compared to rivals' marketing offerings at the same cost as rivals; or

- a market offering perceived as having value equal to rivals' marketing offerings at a lower cost than rivals.

Firms that occupy advantaged market positions often motivate rival firms to take action. That is, competitors that perceive a rival firm as having a competitive advantage will attempt to reduce the effect that the advantage has on them (Hunt, 2000b). As Hunt and Arnett (2001, p. 22) suggest, disadvantaged firms:

\footnotetext{
. attempt to neutralize and/or leap frog the advantage firm(s) by acquisition and or innovation. That is, they attempt to acquire the same resource as the advantage firm(s) and/or they attempt to innovate by imitating the resource, finding an equivalent resource, or finding (creating) a superior resource. Here, "superior" implies that the innovating firm's new resource enables it to surpass the previously advantaged competitor in terms of either relative efficiency, or relative value, or both.
} 
Firms whose innovations are spawned by rival firms' marketplace positions or actions are practicing reactive innovation (Hunt, 2000b). This type of innovation is reactive in the sense that signals from the marketplace inform firms that they occupy marketplace positions of competitive disadvantage, which, in turn, motivates the disadvantaged firms to take strategic actions. This mechanism helps explain why competition is dynamic. By competing for competitive advantages in the marketplace, firms act as disequilibrating forces, which ensures that the marketplace is always changing.

Adding to this dynamism, some firms' innovativeness is a result of their entrepreneurialistic natures. That is, they proactively innovative. Proactive innovation "is innovation by firms that, although motivated by the expectation of superior financial performance, is not prompted by specific competitive pressures - it is genuinely entrepreneurial in the classic sense of entrepreneur" (Arnett and Hunt, 2002, p. 22; italics in original). Entrepreneurialistic firms search constantly for ways to improve the efficiency and/or effectiveness of their organizations. For example, companies like $3 \mathrm{M}$ and Microsoft pride themselves on their ability to integrate innovation into their company cultures, which allows them to practice proactive innovation.

\section{Achieving superior financial performance}

For R-A theory, the goal of firms is superior financial performance. However, "superior" financial performance differs from profit maximization. Although economic agents often prefer more to less, this differs from maximizing (Langlois, 1986). Indeed, R-A theory argues that, though more profits are preferred to less profits, the fact of imperfect information, among other things, prevents firms from profit maximizing.

Because superior equates with both more than and better than, it implies that firms seek a level of performance exceeding some referent. For example, the specific measure of financial performance might be profits, return on assets, or return on equity, whereas the specific referent might be the firm's own performance in a previous time period or that of a set of rival firms, an industry average, or a stock-market average. Both the specific measure and referent will vary from time to time, firm to firm, industry to industry, and culture to culture (italics in original) (Hunt and Morgan, 1997, p. 78).

The distinction between superior financial performance and profit maximization is important. Positing that a firm's goal is superior financial performance reflects the dynamism of R-A theory, which accords well with the extant dynamism of competition in market-based economies (Hunt, 2000b). Positing profit maximization as a firm's goal does not make sense because to achieve maximum profits a firm would need access to, among other things, perfect information about consumers and competitors, which is not possible. Therefore, profit maximization cannot be used as a realistic goal for firms.

R-A theory maintains that superior financial performance is a result of firms occupying positions of competitive advantage in the marketplace. Positions of competitive advantage are a result of consumers perceiving that firms' market offerings have superior value and/or firms' abilities to produce market offerings at lower costs than rivals. These advantages in the marketplace are a result of firms having access to resources that are superior to rivals' resources. In other words, resource advantages lead to positions of competitive advantage and, in turn, superior financial performance (Hunt, 2000b).

\section{Other factors affecting competition}

R-A theory assumes that the environment in which firms compete affects competition. Specifically, the competitive process is significantly influenced by five environmental factors:

1 the societal resources on which firms draw (e.g. availability of skilled workers);

2 the societal institutions that form the "rules of the game" (North, 1990) (e.g. cultural values and beliefs);

3 the actions of competitors and suppliers (e.g. new product launches by rival firms);

4 the behavior of consumers (e.g. trends and fads); and

5 public policy (e.g. antitrust policies).

All of these factors have the ability to foster, neutralize, or destroy a firm's competitive advantage (Hunt, 2000b). For example, firm A may enjoy a marketplace position of competitive advantage because of the value consumers place on its market offerings (e.g. high-quality VCRs). However, firm B innovates and develops new market offerings (e.g., DVD players) based on a better technology. As a result, firm A's original market offerings are no longer a source of longterm competitive advantage. Firm A must now try to find a way to neutralize (or leapfrog) firm B's advantage (e.g. by developing a new technology, such as Blue-Ray ${ }^{\mathrm{TM}}$ ) and the process continues. Add additional firms to the scenario and the dynamics of the typical business's environment become evident.

\section{Grounding the eclectic paradigm in R-A theory}

Evaluating whether R-A theory is capable of providing a theoretical foundation for the eclectic paradigm requires exploring its foundational premises (see Table II). We examine different aspects of R-A theory and show how it meets the five criteria required to theoretically ground the eclectic paradigm. First, we show how R-A theory meets the first four criteria by focusing on how it views resources. Second, we show how it meets the fifth criterion by exploring the concept of competition and organization learning.

Table II The foundational premises of R-A theory

$\mathbf{P}_{1} \quad$ Demand is heterogeneous across industries, heterogeneous within industries, and dynamic

$\mathbf{P}_{2} \quad$ Consumer information is imperfect and costly

$\mathbf{P}_{3} \quad$ Human motivation is constrained self-interest seeking

$\mathbf{P}_{4} \quad$ The firm's objective is superior financial performance

$\mathbf{P}_{5} \quad$ The firm's information is imperfect and costly

$\mathbf{P}_{6}$ The firm's resources are financial, physical, legal, human, organizational, informational, and relational

$\mathbf{P}_{\mathbf{7}} \quad$ Resource characteristics are heterogeneous and imperfectly mobile

$\mathbf{P}_{8}$ The role of management is to recognize, understand, create, select, implement, and modify strategies

$\mathbf{P}_{9} \quad$ Competitive dynamics are disequilibrium-provoking, with innovation endogenous

Note: The foundational propositions of R-A theory are to be interpreted as descriptively realistic of the general case. Specifically, $P_{1}, P_{2}, P_{5}$ and $P_{7}$ for $R-$ A theory are not viewed as idealized states that anchor end-points of continua

Source: Hunt and Morgan (1997) 
An examination of R-A theory reveals that it provides a basis for the existence of ownership advantages and location advantages. R-A theory views ownership advantages as resulting from resource advantages. That is, firms have ownership advantages because of the relative uniqueness of their resource sets, which, in turn, is a result of the relative immobility of many resources (e.g. competencies). As a result, a firm can possess resource advantages over rival firms in foreign markets. For example, strong brand names, such as Coca-Cola and McDonald's, often give firms an advantage over rivals because consumers are already familiar with the company and its products.

Consistent with the eclectic paradigm, R-A theory maintains that firms need not own resources to benefit from them. Firms need only have access to resources. As Hunt (2000b, p. 128) emphasizes:

For example, the relationships involved in relational resources are never owned by firms, but only available to them for the purpose of producing value for some market segment(s). Indeed, just as there is no neoclassical market no demand or supply curve - for "reputations," there is no market for relationships with suppliers, customers, employees, and competitors.

Nonetheless, relational resources have value (italics in original).

Consistent with the eclectic paradigm (Dunning, 2001), R-A theory recognizes that firms can gain access to needed resources by forming cooperative relationships with other firms, for example through contracts and/or strategic alliances (Hunt, 1997a).

R-A theory also maintains that many resources are heritable and durable (Hunt, 2000b). As such, some resources can be transferred across national boundaries. For example, resources, such as production and management processes, can often be used in multiple countries because they can be codified. However, some resources may be situation specific. For example, the skills that a firm's salesforce develop to meet the needs of customers in a particular market may not transfer to other markets because of cultural differences.

Regarding location advantages, R-A theory acknowledges that firms are influenced by environmental factors. Competition among firms is affected by:

- the availability of societal resources;

- the existence of societal institutions;

- the actions of competitors/suppliers;

- the behavior of consumers; and

- public policy.

These factors will differ from country to country because differences exist among countries' forms of government, natural resources, and infrastructures (Hunt, 2000b). When deciding on whether to maintain a presence in a foreign market(s), firms will consider how country-specific environmental factors affect their business operations. Given that each firm has relatively unique resource sets from which to draw, the effects of these environmental factors will vary from firm to firm. For example, some firms' market offerings will match the wants and needs of consumers (an environmental factor) in foreign markets better than others. Therefore, while one firm may decide to invest in a production facility in a foreign country, other firms may decide that such a move is unwise.

R-A theory predicts that superior financial performance in foreign markets will result from occupying marketplace positions of competitive advantage, which is the result of having a comparative advantage in resources. Firms will choose to invest directly in foreign markets if they perceive that their firm-specific resources combined with those available in the foreign marketplace constitute a comparative advantage over rivals' resource sets. In contrast, firms that perceive themselves as being at a resource disadvantage may choose to:

- form partnerships with local firms (to gain access to needed resources);

- form partnerships with other non-local firms (to gain access to needed resources);

- purchase the needed resources; or

- not enter the foreign market.

In reference to internalization advantages, R-A theory recognized that firms are constantly struggling for comparative resource advantages (Hunt, 2000b). As a result, a firm's choice between using its proprietary resources itself (i.e. an internalization strategy) versus making its resources available to other firms will be determined by an evaluation of which strategy will enable it to develop a resource advantage over its rivals. For example, a firm may decide to license its technology to another firm to raise capital that can be used for other projects, which, in turn, provide advantages over rivals. Or, firms may form partnerships with other firms to gain access to each other's resources. For example, firm A may allow firm B to sell its products because firm $B$ has access to markets that firm $A$ does not. In these circumstances, the firm believes that the benefits derived from obtaining access to additional resources outweigh the risk of losing control of proprietary resources.

In summary, R-A theory meets the first four criteria that are necessary if it is to provide a theoretical foundation for the eclectic paradigm. First, it accommodates ownership advantages, location advantages, and internalization advantages and explains how these advantages affect MNE performance. Second, R-A theory advances that resources can be relatively immobile and, therefore, it explains how firms can maintain long-term resource advantages over rivals. Third, it recognizes that some resources available to firms can be used across national boundaries. Fourth, it acknowledges that firms are affected by external environmental factors and that these factors may vary from country to country.

\section{Dynamic MNE competition}

The dynamism of the eclectic paradigm is the result of "the continuous and iterative interaction between OLI configuration over successive time periods and the strategy of firms in response to these configurations that, in turn, influence the OLI configuration in a subsequent moment in time" (Dunning, 2001, p. 178). OLI configurations of firms can be affected by a number of factors, including:

- technological/organizational innovations;

- changes in the composition of senior management;

- increases in labor productivity;

- new marketing techniques; and

- mergers and acquisitions (Dunning, 2001).

These factors, like strategic responses from rivals, can have a profound effect on the effectiveness/efficiency of current OLI configurations, which, in turn, affects the strategies that firms choose to follow in the future and, ultimately, future OLI configurations.

R-A theory views competition as a dynamic process. Given that the objective of firms is superior financial performance, 
firms seek a level of performance that exceeds some referent (e.g. a specific profit level or a certain return on equity). At any given point in time, firms can assess their financial performance (e.g. by comparing projected profits with actual profits for a given time period). The firm's financial performance "signals" to the firm its relative market position, which, in turn, signals relative resources (Hunt and Morgan, 1996). As a result, firms can understand how their current OLI configurations are performing in the marketplace. Poor performance indicates that the current OLI configuration needs modification. In contrast, superior performance signals that current OLI configuration is superior to rivals' configurations and that the firm should make an effort to maintain (or enhance) its current OLI configuration. In addition, R-A Theory explains the role that environmental factors (i.e. societal resources, societal institutions, competitors/suppliers, consumers, and public policy) play in competitive dynamics. Therefore, R-A theory explains the dynamism outlined by the eclectic paradigm and, therefore, meets the fifth criterion necessary to provide a theoretical foundation for the eclectic paradigm.

\section{MNE competition, R-A theory, and the eclectic paradigm}

Many criticisms have been leveled against the eclectic paradigm and whether the OLI framework can continue to be useful given the drastic changes that have occurred concerning globalization. While some researchers suggest that the eclectic paradigm is dead and should be replaced with a better theoretical perspectives (e.g. Mathews, 2006), other researchers suggest that the eclectic paradigm needs to be adapted to still be useful (e.g. Guisinger, 2001, Madhok and Phene, 2001, Tolentino, 2001). However, as Dunning (2001, p. 183) maintains:

The essential postulates of the eclectic paradigm still remain intact and valid irrespective of the motive for MNE activity, its extent, pattern and form still rest on the interaction between the $\mathrm{O}$-specific advantages of investing firms including the willingness and ability of such firms to access new assets and coordinate these with their existing assets - and the advantages of countries and also on relative costs and benefits of engaging in this interaction by alternative modes of governance and noticeably that of administrative fiat (i.e., I advantages).

Dunning (2001) suggests it is not so much a case of extending or adapting the eclectic paradigm as much as finding complementary theories that can work side-by-side with it to explain MNE competition.

R-A theory, because it is a general theory of competition, is capable of providing a broader view of MNE competition than the eclectic paradigm. As a result, it can be used to examine how factors not covered by the eclectic paradigm (e.g. path dependencies) affect MNE behavior. In addition, R-A theory provides a theoretical foundation that can be used to understand how certain concepts and theories interact with and affect those included within the eclectic paradigm. As a result, R-A theory may be capable of expanding our understanding of a number of areas relevant to $\mathrm{MNE}$ research. For example, R-A theory contributes to our understanding of firm diversity (Hunt, 2000b), incorporates the resource based view of the firm (Hunt, 2000a, Hunt and Morgan, 1995), incorporates the competence view of the firm (Hunt, 2000a, b), explicates the effects that public policy decisions have on competition (Hunt and Arnett, 2001), makes the proper prediction regarding financial performance diversity (Hunt, 2000b), explicates that competition is both efficiency seeking and effectiveness seeking (Hunt and Duhan, 2002), argues that firms can have an alliance competence (Lambe et al., 2002; Wittmann et al., 2009), provides a theoretical framework that integrates the dominant theories of business strategy (Hunt and Lambe, 2000), constitutes a phylogenetic, non-consummatory, evolutionary theory of firm behavior (Hunt, 1997a, b; Hunt and Morgan, 1996), grounds endogenous growth models (Hunt, 1997b), recognizes the existence of path dependencies (Hunt and Morgan, 1996), grounds market segmentation strategy (Hunt and Arnett, 2004), and explicates how business strategy can contribute to social welfare (Hunt and Arnett, 2006).

Consider an example of how R-A theory can be used, in conjunction with the eclectic paradigm, to gain insights into MNE competition. The eclectic paradigm provides guidance as to what factors affect whether a firm decides to engage in foreign direct investment strategies. As Dunning (1980) emphasizes a firm will engage in foreign direct investment if: - it possesses resources that rival firms lack (O advantages);

- it is in the best interest of the firm to internalize the advantages (I advantages); and

- the firm's resources complement those of the foreign country (L advantages).

R-A theory, as shown previously, supports the concepts of $\mathrm{O}$ advantages, $\mathrm{L}$ advantages, and I advantages. In addition, R-A theory provides additional predictions concerning foreign direct investment strategies. For example, R-A theory can be used to help explain under what conditions OLI advantages will lead to sustainable competitive advantages for MNEs.

R-A theory maintains that OLI advantages are the result of the unique resource sets available to firms. As R-A theory emphasizes, competitors can neutralize a firm's resource advantage by:

- purchasing the same resources as the advantaged firm;

- imitating the advantaged firm's resources;

- developing strategically equivalent resources; or

- developing strategically superior resources (Hunt, 2000b).

Therefore, MNEs can experience sustainable competitive advantages if the resources that provide the OLI advantages are:

- difficult to imitate;

- not easily substituted for; and

- not easily traded among firms.

According to Hunt (2000b, p. 142), "the major characteristics affecting the lifespan of an advantage are mobility, complexity, interconnectedness, mass efficiencies, tacitness, and time compression diseconomies".

Advantages that rely on mobile resources, which are resources that are easily bought and sold in the marketplace, are often neutralized quickly and effectively by rival firms (Hunt, 2000b). For example, firms can develop advantages over rivals by adopting new technologies, such as state-of-theart manufacturing equipment, before rivals do. However, rivals can quickly negate these types of advantages by adopting new technologies themselves. Therefore, advantages realized from mobile resources are normally short-lived.

In contrast, advantages that stem from complex resources are generally longer lived. For example, Barney (1992) 
discusses socially complex resources, which are described as those "that enable an organization to conceive, choose, and implement strategies because of the values, beliefs, symbols, and interpersonal relationships possessed by individuals or groups in a firm" (p. 45). Socially complex resources (e.g. trust, teamwork, and firm reputation) involve combinations of multiple, often interconnected resources (Hunt, 2000b). Socially complex resources may require a considerable amount of time and effort to develop (i.e. they involve time compression diseconomies) and, in some cases, are not a source of competitive advantage until they reach a "critical mass". For example, firm reputations, such as ones for high quality products or excellent service, lead to competitive advantages only after a large number of consumers believe in their veracity. Dierickx and Cool (1989, p. 1506) describe this phenomenon in terms of stocks and flows:

The fundamental distinction between stocks and flows may be illustrated by the "bathtub" metaphor: at any moment in time, the stock of water is indicated by the level of water in the tub; it is the cumulative result of flows of water into the tub (through the tap) and out of it (through a leak). In the example of R\&D capability, the amount of water in the tub represents the stock of know-how at a particular moment in time, whereas current R\&D spending is represented by the water flowing in through the tap; the fact that know-how depreciates over time is represented by the flow of water leaking through the hole in the tub. A crucial point illustrated by the bathtub metaphor is that while flows can be adjusted instantaneously, stock cannot (italics in original).

As a result, advantages stemming from socially complex resources tend to be difficult to neutralize because of the time needed to increase the "stock" of the resource.

Some resources are difficult to neutralize because they tend to be tacit (e.g. core competencies) and, therefore require time to master. Polanyi (1957) maintains that when one acquires a skill, one also acquires a corresponding understanding that defies articulation (i.e. tacit knowledge). Tacit resources are ones that rely on tacit knowledge and, therefore, are non-codifiable and must be learned by doing (Hunt, 2000b). For example, Lambe et al. (2002) suggest that some firms can develop an alliance competence, which is an organizational capability for securing, developing, and managing alliances (i.e. they tend to be more successful at forming alliances). An alliance competence relies heavily on tacit knowledge. In fact, as Lambe et al. (2002, p. 145) note, developing an alliance competence is such a hands-on learning experience that firms should expect some of their initial attempts to fail. They suggest that to facilitate the development of an alliance competence firms should experiment with less complex alliances and then slowly progress to more complex ones.

\section{Conclusion}

The eclectic paradigm has had considerable influence MNE competition research. Even though all of the elements of the eclectic paradigm are grounded in specific economic or organizational theories, no theory of the fundamental nature of competition in mainstream economics can provide a theoretical foundation for it. Based on the works of Dunning (1958, 1980, 1988, 1998, 2001), five criteria are discussed that should be met by any theory that attempts to theoretically ground the eclectic paradigm. We argue that R-A theory provides a theoretical foundation for the eclectic paradigm.

First, it accommodates ownership advantages, location advantages, and internalization advantages and explains how these advantages affect MNE performance. Second, R-A theory advances that resources can be relatively immobile and, therefore, it explains how firms can maintain long-term resource advantages over rivals. Third, it recognizes that some resources available to firms can be used across national boundaries. Fourth, it acknowledges that firms are affected by external environmental factors and that these factors may vary from country to country. Finally, R-A theory helps explain the dynamism of the eclectic paradigm.

As Hunt (2000, p. 80) suggests, "R-A theory is a work in progress, and much conceptual and empirical work remains to be done". This article represents an initial step toward investigating R-A theory's ability to explain MNE behavior. We have shown that R-A theory does provide a theoretical foundation for the eclectic paradigm. However, the eclectic paradigm is not the only theory that MNE researchers have found useful. Therefore, future research should focus on whether R-A theory is consistent with other successful approaches explaining MNE behaviors. Potential approaches include:

- internationalization theory (Buckley, 1988; Rugman, 1982);

- classical trade theory (Ricardo, 1817, Smith, 1961);

- regional integration theory (Balassa, 1961; Eden, 2002);

- factor proportion theory (Hecksher and Ohlin, 1933);

- institutional theory (Dacin et al., 2002; Kostova et al., 2008); and

- $\quad$ product life cycle theory (Vernon, 1966; Wells, 1968).

Comparisons of these approaches to that of R-A theory may yield additional insights into MNE competition and will also provide a more thorough examination of R-A theory as a general theory of competition.

\section{Notes}

1 This sentence draws on Rudner's (1966) definition of a theory.

2 The overview presented here is extremely brief. For a more thorough discussion of the theory see Hunt (2000b).

3 It should be noted that R-A theory does more than just incorporate concepts from these theories. It also integrates and extends them. For example, while R-A theory adopts a resource-based view of the firm, it does not view the process of competition as an equilibrium-seeking process as do many resource-based theorists (see Schulze, 1994). Instead, it maintains that firms seek superior resources, which promotes disequilibrium in the marketplace (Hunt, 2000b).

\section{References}

Alderson, W. (1965), Dynamic Marketing Behavior, Richard D. Irwin, Homewood, IL.

Arnett, D.B. and Hunt, S.D. (2002), "Competitive irrationality: the influence of moral philosophy", Business Ethics Quarterly, Vol. 12 No. 3, pp. 279-303.

Balassa, B. (1961), The Theory of Economic Integration, Richard D. Irwin, Homewood, IL.

Barney, J. (1992), "Integrating organizational behavior and strategy formulation research: a resource-based analysis", in Shrivastava, P., Hugg, A.S. and Dutton, J.E. (Eds), Advances in Strategic Management, JAI Press, Greenwich, CT. 
Buckley, P.J. (1988), "The limits of explanation: testing the internationalisation theory of the multinational", fournal of International Business Studies, Vol. 19 No. 2, pp. 181-93.

Burt, R.S. (1992), Structural Holes: The Social Structure of Competition., Harvard University Press, Cambridge, MA.

Cantwell, J. and Narula, J. (2001), "The eclectic paradigm in the global economy", International fournal of the Economics of Business, Vol. 8 No. 2, pp. 155-72.

Coase, R.H. (1988), "The nature of the firm: influence", fournal of Law, Economics and Organizations, Vol. 4 No. 1, pp. 33-47.

Dacin, M.T., Goodstein, J. and Scott, W. (2002), "Institutional theory and institutional change: introduction to the special research forum", Academy of Management fournal, Vol. 45 No. 1, pp. 45-57.

Dierickx, I. and Cool, K. (1989), "Asset stock accumulation and sustainable competitive advantage", Management Science, Vol. 35 No. 12, pp. 1504-11.

Dunning, J.H. (1958), American Investment in British Manufacturing Industry, Allen \& Unwin, London.

Dunning, J.H. (1980), "Toward an eclectic theory of international production: some empirical tests", fournal of International Business Studies, Vol. 11 No. 1, pp. 23-31.

Dunning, J.H. (1988), "The eclectic paradigm of international production: a restatement and some possible extensions", Fournal of International Business Studies, Vol. 19 No. 1, pp. 1-31.

Dunning, J.H. (1998), "Location and the multinational enterprise: a neglected factor?", Fournal of International Business Studies, Vol. 29 No. 1, pp. 45-66.

Dunning, J.H. (2001), "The eclectic (OLI) paradigm of international production: past, present, and future", International fournal of Economics of Business, Vol. 8 No. 2, pp. $173-90$.

Dunning, J.H. (2003), “The contribution of Edith Penrose to international business scholarship", Management International Review, Vol. 43 No. 1, pp. 3-19.

Dunning, J.H. and Lundan, S.M. (2008), "Institutions and the OLI paradigm of the multinational enterprise", Asia Pacific Fournal of Management, Vol. 25 No. 4, pp. 573-93.

Dunning, J.H. and McQueen, M. (1981), "The eclectic theory of international production: a case study of the international hotel industry", Managerial and Decision Economics, Vol. 2 No. 4, pp. 1-15.

Dunning, J.H. and Norman, G. (1983), "The theory of the multinational enterprise: an application to multinational office location", Environment and Planning, Series A, Vol. 15 No. 5, pp. 75-92.

Eden, L. (2002), "Regional integration and foreign direct investment: theory and lessons from NAFTA", in Kotabe, M. and Aulakh, P.S. (Eds), Emerging Issues in International Research, Edward Elgar, Cheltenham.

Feldman, J.M. (2001), "Southwest keeps moving", Air Transport World, Vol. 38 No. 11, pp. 48-9.

Foss, N. (1993), "Theories of the firm: contractual and competence perspectives", Fournal of Evolutionary Economics, Vol. 3 No. 2, pp. 127-44.

Foss, N. (1996), "More critical comments on knowledgebased theories of the firm", Organization Science, Vol. 7 No. 5, pp. 519-23.

Graham, E.M. (1998), "Market structure and multinational enterprise: a game-theoretical approach", International Fournal of Economics of Business, Vol. 29 No. 1, pp. 67-83.
Grosse, R. (1985), "An imperfect competition theory of the MNE", Fournal of International Business Studies, Vol. 16 No. 1, pp. 57-80.

Guisinger, S. (2001), "From OLI to OLMA: incorporating higher levels of environmental and structural complexity into the eclectic paradigm", International fournal of Economics of Business, Vol. 8 No. 2, pp. 257-72.

Hecksher, E. and Ohlin, B. (1933), Interregional and International Trade, Harvard University Press, Cambridge, MA.

Horaguchi, H. and Toyne, B. (1990), "Setting the record straight: Hymer, internationalization theory and transaction cost economics", fournal of International Business Studies, Vol. 21 No. 3, pp. 487-94.

Hunt, S.D. (1997a), "Competing through relationships: grounding relationship marketing in resource advantage theory", Fournal of Marketing Management, Vol. 13 No. 5, pp. 431-45.

Hunt, S.D. (1997b), "Evolutionary economics, endogenous growth models, and resource-advantage theory", Eastern Economic fournal, Vol. 23 No. 4, pp. 427-41.

Hunt, S.D. (2000a), "The competence-based, resourceadvantage, and neoclassical theories of competition: toward a synthesis", in Sanchez, R. and Heene, A. (Eds), Theory Development for Competence-Based Management, JAI Press, Greenwich, CT.

Hunt, S.D. (2000b), A General Theory of Competition, Sage Publications, Thousand Oaks, CA.

Hunt, S.D. and Arnett, D.B. (2001), "Competition as an evolutionary process and antitrust policy", fournal of Public Policy and Marketing, Vol. 20 No. 1, pp. 15-26.

Hunt, S.D. and Arnett, D.B. (2004), "Market segmentation strategy, competitive advantage, and firm performance: grounding market segmentation strategy in resourceadvantage theory", Australasian Marketing fournal, Vol. 12 No. 1, pp. 7-25.

Hunt, S.D. and Arnett, D.B. (2006), "Does marketing success lead to market success?", fournal of Business Research, Vol. 59 No. 7, pp. 820-8.

Hunt, S.D. and Duhan, D.F. (2002), "Competition in the third millennium: efficiency or effectiveness?", fournal of Business Research, Vol. 55 No. 2, pp. 97-112.

Hunt, S.D. and Lambe, C.J. (2000), “Marketing's contribution to business strategy: market orientation, relationship marketing, and resource-advantage theory", International fournal of Management Review, Vol. 2 No. 1, pp. 17-43.

Hunt, S.D. and Madhavaram, S. (2006), "Teaching marketing strategy: using resource-advantage theory as an integrative theoretical foundation", fournal of Marketing Education, Vol. 28 No. 2, pp. 93-105.

Hunt, S.D. and Morgan, R.M. (1995), "The comparative advantage theory of competition", fournal of Marketing, Vol. 59 No. 2, pp. 1-15.

Hunt, S.D. and Morgan, R.M. (1996), "The resourceadvantage theory of competition: dynamics, path dependencies, and evolutionary dimensions", fournal of Marketing, Vol. 60 No. 4, pp. 107-14.

Hunt, S.D. and Morgan, R.M. (1997), "Resource-advantage theory: a snake swallowing its tail or a general theory of competition?", Fournal of Marketing, Vol. 60 No. 3, pp. 107-14. 
Kostova, T., Roth, K. and Dacin, M.T. (2008), "Institutional theory in the study of multinational corporations: a critique and new directions", Academy of Management Review, Vol. 33 No. 4, pp. 994-1006.

Lambe, C.J., Spekman, R.E. and Hunt, S.D. (2002), "Alliance competence and alliance success: conceptualization, measurement, and initial test", fournal of the Academy of Marketing Science, Vol. 30 No. 2, pp. 141-59.

Langlois, R.N. (1986), Firms, Markets, and Economic Change: A Dynamic Theory of Business Institutions, Cambridge University Press, Cambridge.

Langlois, R.N. and Robertson, P.L. (1995), Firms, Markets, and Economic Change: A Dynamic Theory of Business Institutions, Routledge, London.

Madhok, A. and Phene, A. (2001), "The co-evolution advantage: strategic management theory and the eclectic paradigm", International Fournal of the Economics of Business, Vol. 8 No. 2, pp. 243-56.

Mathews, J.A. (2006), "Dragon multinationals: new players in the 21st century globalization", Asia Pacific fournal of Management, Vol. 23 No. 1, pp. 5-27.

Moore, K. and Lewis, D. (1999), Birth of the Multinational, Copenhagen Business School Press, Copenhagen.

North, D.C. (1990), Institutions, Institutional Change, and Economic Performance, University of Cambridge Press, Cambridge.

Penrose, E.T. (1959), The Theory of the Growth of the Firm, Basil Blackwell \& Mott, London.

Polanyi, M. (1957), Personal Knowledge: Towards a Post-Critical Philosophy, Routledge and Kegan Paul, London.

Ricardo, D. (1817), "Principles of political economy", in Saffra, P. (Ed.), The Works and Correspondence of David Ricardo, Vol. 1, Cambridge University Press, Cambridge.

Rudner, R. (1966), Philosophy of Social Science, Prentice Hall, Englewood Cliffs, NJ.

Rugman, A.M. (1982), "Internationalization and non-equity forms of international involvement", New Theories of the Multinational Enterprise, Croom Helm, London.

Schulze, T. (1994), "The two schools of thought in resourcebased theory", in Shrivaastava, P., Huff, A.S. and Dutton, J.E. (Eds), Advances in Strategic Management, Vol. 10A, JAI Press, Greenwich, CT.

Smelser, N.J. and Swedberg, R. (1994), The Handbook of Economic Sociology, Princeton University Press, Princeton, NJ.

Smith, A. (1961) in Cannon, E. (Ed.), An Inquiry into the Nature and Causes of the Wealth of Nations, Methuen, London, (first published 1776).

Teece, D. and Pisano, G. (1994), "The dynamic capabilities of firms", Industrial and Corporate Change, Vol. 3 No. 3, pp. 537-56.

Tolentino, P.E. (2001), "From a theory to a paradigm: examining the eclectic paradigm as a framework in international economics", International fournal of the Economics of Business, Vol. 8 No. 2, pp. 191-209.

Vernon, R. (1966), "International investment and international trade in the product cycle", Quarterly Fournal of Economics, Vol. 80 No. 2, pp. 190-207.

Wells, L.T. (1968), "A product life cycle for international trade?”, Fournal of Marketing, Vol. 33 No. 3, pp. 1-6.

Wernerfelt, B. (1984), "A resource-based view of the firm", Strategic Management Fournal, Vol. 5 No. 3, pp. 171-80.

Williamson, O.E. (1975), Markets and Hierarchies: Analysis and Anti-trust Implication, The Free Press, New York, NY.

Williamson, O.E. (1985), The Economic Institutions of Capitalism, The Free Press, New York, NY.

Williamson, O.E. (1996), The Mechanisms of Governance, Oxford University Press, Oxford.

Wittmann, C.M., Hunt, S.D. and Arnett, D.B. (2009), "Explaining alliance success: competences, resources, relational factors, and resource-advantage theory", Industrial Marketing Management, Vol. 38 No. 7, pp. 743-56.

\section{Further reading}

Falkenberg, A.W. (2000), "Competition and markets", fournal of Macromarketing, Vol. 20 No. 1, pp. 8-9.

\section{About the authors}

Dennis B. Arnett ( $\mathrm{PhD}$, Texas Tech University) is the John B. Malouf Professor of Marketing at the Rawls College of Business, Texas Tech University (Lubbock, TX). He is also a member of the faculty at Buskerud University College (Hønefoss, Norway). His research focuses on two interrelated areas: competition theory and its implications for marketing theory and practice, and relationship marketing theory. His research has appeared in fournal of Marketing, Fournal of Public Policy \& Marketing, Fournal of Retailing, Fournal of Marketing Theory and Practice, Fournal of Business Research, Fournal of Business $\mathcal{E}$ Industrial Marketing, Fournal of Personal Selling and Sales Management, Industrial Marketing Management, and others. Dennis B. Arnett is the corresponding author and can be contacted at: dennis.arnett@ttu.edu

Sreedhar Madhavaram (PhD, Texas Tech University) is an Associate Professor of Marketing at Cleveland State University. His work has been published in or has been accepted for publication in Industrial Marketing Management, Fournal of Advertising, Fournal of Business \& Industrial Marketing, Fournal of Marketing Education, fournal of Personal Selling $\mathcal{E}$ Sales Management, Fournal of the Academy of Marketing Science, Marketing Education Review, Psychology $\mathcal{E}$ Marketing, and others. A frequent presenter at national and international conferences, his research interests include marketing strategy, marketing theory and concepts, marketing communications, marketing pedagogy, organizational knowledge, and sales management. 